\title{
LEGAL PROTECTION AGAINST CHILDREN ONLINE PORNOGRAPHIC CRIME OBJECTS BASED ON LAW OF THE REPUBLIC OF INDONESIA NUMBER 44 OF 2008 CONCERNING PORNOGRAPHY
}

\author{
Amsori and Debby Rizky Isnia \\ Departement of Law, IBLAM School of Law \\ Jalan Kramat Raya No.25, Jakarta Pusat
}

\begin{abstract}
Abstrack
The issue of legal protection for children who are the object of crime in Indonesia is very important because they are the future generation of the nation. One of the threats to children is the influence of online pornography, where the online world is now common to society. So that the public knows whether the state has made efforts to provide legal protection for children who are objects of online pornography crimes through the Pornography Law and to find out the extent to which the Pornography Law is used as a reference to get legal protection from perpetrators of online pornography crimes. In this research, it is analyzed juridically with deductive explanation regarding the provisions contained in the Law on Pornography in relation to the legal protection of children as objects of pornography crimes. It was found that since the early part of the Pornography Law has shown the spirit of legal protection for children starting from the definition of age limits categorized as children, the purpose of the law which clearly contains the words to protect children, to criminal provisions that stipulate an additional sentence of one third of the maximum a criminal threat if the pornographic crime involves a child. In decision Number 1363 / Pid.Sus / 2017 / PN JKT.SEL, the Pornography Law is mentioned as a reference in the ruling other than the Law on Electronic Information and Transactions, however in imprisonment and fines in the verdict it does not indicate that what was used is a criminal provision in the Pornography Law. In fact, according to the Criminal Code, if there are different rules, the heavier the criminal provisions are used. From the foregoing, it can be seen that the Pornography Law is here to answer the need for legal protection for children as objects of online pornography crimes. Then, criminal decisions related to pornography crimes should consistently refer to the Pornography Law in order to play an optimal role in preventing similar crimes from recurring and ensuring legal protection for children.
\end{abstract}

Keywords: Legal Protection, Children as Objects of Online Pornography Crime, Pornography Law 


\title{
PERLINDUNGAN HUKUM TERHADAP ANAK OBJEK KEJAHATAN PORNOGRAFI ONLINE BERDASARKAN UNDANG-UNDANG REPUBLIK INDONESIA NOMOR 44 TAHUN 2008 TENTANG PORNOGRAFI
}

Studi Kasus Putusan Nomor 1363/Pid.Sus/2017/PN JKT.SEL

\author{
Amsori dan Debby Rizky Isnia \\ Program Studi Sarjana Hukum, Sekolah Tinggi Ilmu Hukum IBLAM \\ Jalan Kramat Raya No. 25 Jakarta Pusat
}

\section{Intisari}

Masalah perlindungan hukum terhadap anak yang menjadi objek kejahatan di Indonesia sangat penting karena mereka adalah generasi penerus masa depan bangsa. Salah satu ancaman bagi anak adalah pengaruh pornografi online dimana dunia online saat ini adalah hal yang umum bagi masyarakat. Agar masyarakat mengetahui apakah negara telah berupaya memberikan perlindungan hukum terhadap anak objek kejahatan pornografi online melalui Undang-Undang Pornografi dan untuk mengetahui sejauh mana Undang-Undang Pornografi dijadikan sebagai acuan mendapatkan perlindungan hukum dari pelaku kejahatan pornografi online. Pada penelitian ini dianalisa secara yuridis dengan pemaparan deduktif mengenai ketentuan-ketentuan yang tercantum dalam Undang-Undang Pornografi dalam kaitannya dengan perlindungan hukum anak objek kejahatan pornografi. Didapati bahwa sejak bagian awal Undang-Undang Pornografi telah menunjukkan semangat perlindungan hukum terhadap anak dimulai dari definisi batasan usia yang dikategorikan anak, tujuan Undang-Undang yang dengan jelas memuat kata-kata melindungi anak, hingga ketentuan pidana yang mengatur adanya tambahan hukuman sepertiga dari maksimum ancaman pidana jika kejahatan pornografi melibatkan anak. Dalam putusan Nomor 1363/Pid.Sus/2017/PN JKT.SEL, Undang-Undang Pornografi disebutkan sebagai acuan dalam amar putusan selain Undang-Undang Informasi dan Transaksi Elektronik, namun dalam penjatuhan pidana penjara dan pidana denda dalam putusan tidak menunjukkan bahwa yang digunakan adalah ketentuan pidana dalam Undang-Undang Pornografi. Padahal menurut Kitab Undang-Undang Hukum Pidana, jika ada aturan yang berbeda maka yang lebih berat ketentuan pidananya yang digunakan. Dari hal tersebut di atas dapat terlihat bahwa Undang-Undang Pornografi sudah hadir untuk menjawab kebutuhan perlindungan hukum terhadap anak objek kejahatan pornografi online. Kemudian putusan pidana terkait kejahatan pornografi sebaiknya konsisten mengacu kepada Undang-Undang Pornografi agar dapat berperan optimal dalam pencegahan terjadinya kejahatan serupa terulang kembali dan menjamin perlindungan hukum bagi anak.

Kata Kunci : Perlindungan Hukum, Anak Objek Kejahatan Pornografi Online, Undang-Undang Pornografi 


\section{A. Pendahuluan}

Perkembangan dunia senantiasa membawa sisi baik dan sisi buruk. Ibarat dua sisi mata uang yang gambarnya kerap berbeda, konsekuensinya secara perseptif pun berbeda. Termasuk salah satunya adalah perkembangan dunia di sisi informasi dan komunikasi. Saat ini dengan semakin berkembangnya dunia digital, mendapatkan informasi atau berkomunikasi antar manusia menjadi semakin mudah. Namun di balik kemudahan itu tentunya dapat membawa kesulitan yang lebih rumit dibandingkan sebelumnya.

Kemudahan akses informasi dan komunikasi saat ini tidak hanya menyentuh kalangan dewasa, namun anak pun merasakannya dimana saat ini sudah sangat biasa dijumpai di area publik ataupun di kehidupan sehari-hari saat kita bertamu ke salah satu rumah tangga, sang anak terlihat sangat menikmati menekan tomboltombol layar sentuh alat komunikasi handphone di saat di era sebelumnya, anak-anak lebih memilih untuk bermain bersama temannya di luar rumah, bermain layangan, jungkatjungkit, bersepeda, tapak gunung, galah asin, sepak bola, bulu tangkis dan berbagai aktivitas yang sangat baik untuk sensor motorik anak.

Kemudahan itu tidak pernah didapatkan oleh anak-anak di era sebelumnya dimana hingga sebelum booming-nya gadget atau dikenal dalam istilah bahasa indonesia sebagai gawai, sarana komunikasi adalah dominasi kalangan dewasa yang hanya menggunakannya untuk mempermudah komunikasi dalam bekerja. Anak-anak era sebelumnya (bisa dikatakan di bawah tahun 2000) hanya berkomunikasi dengan anak sebaya atau sepantarannya atau dalam lingkungan terbatasnya dan untuk mendapatkan informasi pun sebatas hanya di media massa cetak atau televisi atau radio.

Terbatasnya akses informasi maupun komunikasi anak di era sebelumnya membuat mereka juga terbatas aksesnya kepada orang asing dan informasi asing yang saat ini dengan begitu mudahnya muncul di depan mata seorang anak begitu saja dengan cukup menekan tombol demi tombol layar sentuh handphone.

Keterbatasan itu seakan-akan terlihat sebagai hal yang menghambat perkembangan anak pada masa itu, namun di satu sisi dapat pula menjadi pelindung kemurnian dunia anak mereka karena orang tua atau keluarganya dapat mengetahui batasan pikiran atau pengetahuan si anak karena untuk hal yang tidak dapat mereka langsung lihat atau ketahui begitu saja, mereka cenderung akan bertanya ke orang tua atau keluarganya.

Saat ini keterbatasan akses informasi dan komunikasi anak sudah sangat jauh berbeda dibandingkan masa itu, dikarenakan orang tua kebanyakan telah memberikan handphone kepada anak dengan berbagai alasan, semisal agar tidak merasa berbeda dibandingkan rekan sebayanya, mempermudah belajar, atau pengalih fokus agar anak tidak bermain di luar karena berita demi berita di televisi atau media massa lainnya yang semakin banyak yang memberitakan bahaya orang asing bagi anak sehingga membiarkan anak 
bermain di luar rumah saat ini menjadi suatu hal yang paranoid bagi orang tua.

Tujuan baik dari orang tua untuk memberikan perlindungan bagi anaknya ini terkadang memberikan sisi negatif, baik untuk perkembangan sensor motorik bagi si anak maupun orang tua tidak lagi mempunyai filter (saringan) apa yang dilakukan anak di dunia maya yang bagaikan jagad tak berbatas. Dalam bahasa lain, orang tua hanya dapat melihat fisik anaknya secara terus-menerus berada di dekatnya baik itu di rumah atau di kendaraan, namun orang tua tidak dapat melihat pikiran anaknya sedang menerawang ke bagian mana dari jagad dunia maya.

Pikiran anak salah satunya dipicu dari apa yang dia lihat, termasuk apa yang dia lihat melalui handphone, komputer atau perangkat lain yang digunakannya untuk mengakses informasi atau berkomunikasi. Hal tersebut sangatlah riskan dimana saat ini berbagai macam informasi kadang muncul begitu saja di layar handphone atau laptop. Informasi itu biasanya berbentuk pop up promosi yang mengundang anak untuk terus melakukan klik pada hal-hal yang dianggapnya baru atau menarik.

Adanya klik yang dilakukan anak tidak menutup kemungkinan akan mengarahkannya ke informasi baru yang belum pantas untuk usianya maupun berkenalan dengan orang dewasa dengan niat jahat. Baik anak tersebut dijadikan sebagai obyek kejahatan atau dibuat tertarik untuk melihat hasil kejahatan pun bisa terjadi mengingat orang tua atau keluarga belum tentu bisa memonitor apa yang anak tersebut lakukan di dunia maya (internet) secara online.
Salah satu berita terkait kriminalitas dalam hubungannya dengan perilaku online ini adalah Polda Metro menangkap para tersangka tindak pornografi online anak. Mereka diduga memperjualbelikan video berkonten pornografi anak dengan sesama jenis atau dikenal dengan video gay kids (VGK). Dalam kasus video gay kids (VGK), Tersangka YUL yang berperan sebagai admin akun twitter@VGKSale dan grup telegram VGK Premium. YUL dibekuk di kediamannya, Purworejo, Jawa Tengah, pada 5 September 2017. HER alias UHER yang berperan sebagai penyedia konten melalui akun twitter@NeoHermawan2 dan @febrifebri745, ditangkap di Garut, Jawa Barat, pada 7 September 2017. Sedangkan tersangka IK yang merupakan pengguna akun twitter @ FreeVGK69 dan blog pribadinya freevgk.blogspot.co.id diringkus di Bogor, Jawa Barat. Para pelaku bergabung dalam berbagai grup aplikasi seperti Telegram dan Whatsapp untuk mendapatkan foto dan video gay kids tersebut. Dan mereka memiliki afiliasi dengan 49 negara untuk mencari, menjual, dan menyebarluaskan konten foto dan video pornografi anak. Masingmasing tersangka memiliki follower kurang lebih dari 1.000 orang. ${ }^{1}$

Hukum yang kerap digunakan untuk penanganan kasus-kasus seperti ini adalah Undang-Undang Pornografi dan Undang-Undang Informasi dan

\footnotetext{
1 Icjr.or.id. Institute for Criminal Justice Reform. https://icjr.or.id/pengungkapan-kasusvideo-gay-kids-vgk-langkah-majupemberantasan-child-online-pornography-copdi-indonesia/, (diakses pada 9 April 2020 pukul 11.05)
} 
Transaksi Elektronik. Terkait berita kriminalitas di atas, salah satu pelaku telah diputus melakukan tindak pidana oleh Pengadilan Negeri Jakarta Selatan melalui Putusan Nomor 1363/Pid.Sus/2017/PN JKT.SEL. Berdasarkan latar belakang tersebut, penulis merumuskan judul skripsi "Perlindungan Hukum Terhadap Anak Objek Kejahatan Pornografi Online Berdasarkan Undang-Undang Republik Indonesia Nomor 44 Tahun 2008 Tentang Pornografi (Studi Kasus Putusan Nomor 1363/Pid.Sus/2017/PN JKT.SEL)". Selain dari pemilihan studi kasus diatas ada lagi beberapa yang menjadi pendorong dilakukannya penelitian dengan memilih judul ini adalah diantaranya:

\section{B. Metode Penelitian}

Metode yuridis normatif, artinya data yang digunakan berasal dari studi kepustakaan, dilakukan dengan mencari, mengutip, mencatat, menginventarisasi, menganilisis, dan mempelajari data berupa bahan-bahan pustaka yang dibutuhkan dan berhubungan dengan penegakan hukum terhadap pelaku tindak pidana pencurian dengan pemberatan Perlindungan hukum terhadap anak objek kejahatan ponografi online berdsarkan undang - undang Republik Indonesia Nomor 44 Tahuu 2008 tentang pornografi.

\section{Pengaruh Media Massa Online dan Perlindungan Hukumnya}

Media komputer memiliki kualitas atraktif yang dapat merespon segala stimulus yang diberikan oleh penggunanya. Terlalu atraktifnya membuat penggunanya seakan-akan menemukan dunianya sendiri yang membuatnya merasa nyaman dan tidak mau melepaskannya. Contohnya banyak aplikasi yang ada di komputer serta di handphone, membuat semua orang mudah untuk menggunakannya seperti game online dan lainnya. ${ }^{2}$

Para ilmuwan sosial telah membuktikan bahwa pesan-pesan yang disampaikan melalui media massa (televisi, radio, film, internet, surat kabar, makalah, buku, dan seterusnya) memberikan pengaruh bagi perkembangan diri seseorang, terutama anak-anak. Beberapa penelitian menyatakan bahwa sebagian besar waktu anak-anak dan remaja dihabiskan untuk menonton televisi, bermain game online dan berkomunikasi melalui internet, seperti contohnya facebook. Banyak pihak mengaku bahwa media massa telah berperan dalam proses homogenisasi, sehingga masyarakat dari berbagai belahan dunia memiliki struktur dan kecenderungan cara hidup yang sama. ${ }^{3}$

Teori Jarum hipodermik yang menyatakan media massa sangat berpengaruh dilandasi konsepsi behaviorisme yang memandang manusia sebagai mahluk yang digerakkan semaunya oleh lingkungan (Homo Mechanicus). Teori pengelolaan informasi dibentuk oleh konsepsi psikologi kognitif yang melihat manusia sebagai makhluk yang aktif mengorganisasikan dan

\footnotetext{
2 Aris Kurniawan, "Teknologi Informasi dan Komunikasi - Sejarah, Pengertian, Manfaat, Dampak, Pengelompokan, Komponen, Pendidikan, Klasifikasi", https://www.gurupendidikan.co.id/teknologiinformasi-dan-komunikasi// (diakses pada 2 April 2020 pukul 09.35)

3 Hendra Akhdhiat \& Rosleny Marliani, Psikologi Hukum (Bandung : CV Pustaka Setia, 2011), h.41
} 
mengelola stimulus yang diterimanya (Homo Sapiens). Teori-teori komunikasi interpersonal banyak dipengaruhi konsepsi psikologi humanistis yang menggambarkan manusia sebagai pelaku aktif dalam meneruskan strategi transaksional dengan lingkungan (Homo Ludens). ${ }^{4}$ Salah satu efek negatif penggunaan media massa ini adalah adanya berbagai aplikasi dan situs yang memudahkan para perilaku kejahatan berperan untuk memuaskan hasratnya sendiri dan kemudian membuka situs yang berbau pornografi dan menindaklanjutinya dengan melakukan jebakan pada orang lain untuk melayani hasratnya.

Dengan demikian, hukum dan pendidikan memainkan peran sentral di dalam pemikiran fungsionalis dalam memastikan pelaksanaan peran secara baik. Masyarakat harus dididik untuk melaksanakan peran mereka dengan tujuan untuk menjamin keharmonisan sosial. Hukum dan sistem hukum karenanya memainkan peran dalam memenuhi salah satu dari prasyarat-prasyarat fungsional dalam persepsi Parsons tentang masyarakat. ${ }^{5}$

Roscoe Pound mengkaji hukum dari sudut pandang konflik kepentingan dan nilai. Dalam pandangan Pound, hukum bukan hanya merupakan kumpulan normanorma abstrak atau suatu tertib hukum, tetapi juga merupakan suatu proses (process) untuk mengadakan keseimbangan antara kepentingankepentingan dan nilai-nilai yang saling bertentangan. Proses itu pada

4 Jalaluddin Rakhmat, Psikologi Komunikasi (Bandung : Remaja Rosdakarya, 2012), h.18

5 Achmad Ali, Sosiologi Hukum : Kajian Empiris Terhadap Pengadilan (Jakarta : Penerbit STIH IBLAM, 2004), h.101-102 akhirnya melahirkan keseimbangankeseimbangan baru membuat masyarakat terekayasa menuju keadaan baru yang lebih baik dengan keseimbangan-keseimbangan baru.

Pound tidak menunjuk pihak tertentu sebagai yang paling berjasa untuk merekayasa masyarakat menuju keseimbangan-keseimbangan yang baru. Dengan demikian, semua pihak, baik anggota masyarakat yang melakukan unjuk rasa, mass media yang membentuk pendapat umum (public opinion), hakim yang menjatuhkan putusan dalam hal suatu perkara dibawa ke pengadilan, maupun pemerintah yang membuat peraturan perundang-undangan, memiliki perannya masing-masing dalam melahirkan keseimbangankeseimbangan yang baru tersebut.

Contohnya, di Amerika Serikat dahulu ada konflik kepentingan antara pengusaha (business) dengan masyarakat di sekitar perusahaan, yang pada akhirnya melahirkan konsep moral tentang tanggung jawab sosial dari pengusaha (social responsibility of business). Dalam pandangan teori ini, hukum tidak berada di belakang atau di depan perkembangan masyarakat karena hukum adalah proses perkembangan masyarakat itu sendiri. ${ }^{6}$

Ada perbedaan antara tugas pembentuk Undang-Undang dan tugas hakim. Tugas pembentuk UndangUndang adalah hanya merumuskan aturan umum, sedangkan tugas hakim adalah tidak hanya menerapkan Undang-Undang, tetapi berdasarkan asas-asas yang dirumuskan oleh pembentuk Undang-Undang menerapkannya pada perbuatan

\footnotetext{
6 Donald Albert Rumokoy \& Frans Marantis, op.cit, h.36-37
} 
factual. Sejalan dengan itu patut diperhatikan apa yang dikatakan oleh Paul Scholten tentang Open Systeem van het recht (sistem terbukanya umum) bahwa setiap putusan hakim, sebagai unsur yang mandiri selalu menemukan sesuatu yang baru. ${ }^{7}$

Teori Muller dalam tulisannya "De Straf in het Strafrecht", Tijdschrift van Strafech, 44 (1935) yang mengatakan bahwa akibat preventif pidana tidaklah terletak pada eksekusi pidana maupun dalam ancaman pidana, tetapi pada penentuan pidana oleh hakim secara konkret (de concrete straf pleging door de rechter). Dalam teori ini delik dipertanggungjawabkan kepada golongan orang tertentu. Ada anasir mendidik dalam teori ini. Menurut Utrecht teori Muller ini sesuai dengan masyarakat kolektivistis dan mungkin pada kemudian hari hukum pidana Indonesia (mengingat hukum adat) akan lebih kolektif.

Prevensi khusus yang dianut oleh Van Hamel (Belanda) dan Von Liszt (Jerman) mengatakan bahwa tujuan prevensi khusus ialah mencegah niat buruk pelaku (dader) bertujuan mencegah pelanggar mengulangi perbuatannya atau mencegah bakal pelanggar melaksanakan perbuatan jahat yang direncanakannya. Van Hamel menunjukkan bahwa prevensi khusus suatu pidana ialah :

1. Pidana harus memuat suatu unsur menakutkan supaya mencegah penjahat yang mempunyai kesempatan untuk tidak melaksanakan niat buruknya.

${ }^{7}$ Ibid, h.25

8 Andi Hamzah, Asas-Asas Hukum Pidana (Jakarta : Rineka Cipta, 2010), h.35
2. Pidana harus mempunyai unsur memperbaiki terpidana.

3. Pidana mempunyai unsur membinasakan penjahat yang tidak mungkin diperbaiki.

4. Tujuan satu-satunya suatu pidana ialah mempertahankan tata tertib hukum. ${ }^{9}$

Mengenai penerapan dari pidana ini, ada pendapat yang menyatakan bahwa pemenjaraan yang singkat justru banyak segi negatifnya, yaitu penjahat pemula yang kecil-kecilan dapat berguru di penjara kepada penjahat kawakan dan residivis, sehingga tujuan pemasyarakatan justru tidak tercapai, bahkan sebaliknya. ${ }^{10}$

Dalam konstitusi suatu negara salah satu materinya adalah mengenai jaminan perlindungan hak-hak asasi manusia bagi warga negaranya. Demikian juga dengan konstitusi atau undang-undang dasar Negara Republik Indonesia. ${ }^{11}$

\section{Hasil Penelitian dan Pembahasan}

Hak Anak untuk Mendapatkan Perlindungan Hukum

Undang-Undang Perlindungan Anak Pasal 67A menyebutkan Setiap Orang wajib melindungi Anak dari pengaruh pornografi dan mencegah akses Anak terhadap informasi yang mengandung unsur pornografi. ${ }^{12}$

Undang-Undang Perlindungan Anak Pasal 69 berisi tentang ketentuan perlindungan khusus bagi anak korban kekerasan fisik dan/atau psikis yakni dilakukan melalui upaya :

\footnotetext{
9 Ibid, h.36

10 lbid, h.30

${ }^{11}$ Muchsin, Ikhtisar Sejarah Hukum (Jakarta : Penerbit STIH IBLAM, 2004), h.45

${ }^{12}$ lbid.
} 
a. penyebarluasan dan sosialisasi ketentuan peraturan perundangundangan yang melindungi Anak korban tindak Kekerasan; dan

b. pemantauan, pelaporan, dan pemberian sanksi. ${ }^{13}$

Selain itu mengenai hak-hak seorang anak secara rinci diatur dalam Undang-Undang Nomor 4 Tahun 1979 tentang Kesejahteraan Anak. Berdasarkan ketentuan UndangUndang Nomor 4 Tahun 1979 tentang Kesejahteraan Anak sebagai upaya untuk menjamin terwujudnya kesejahteraan anak, yaitu suatu tata kehidupan dan penghidupan anak yang dapat menjamin pertumbuhan dengan wajar, baik secara rohani, jasmani, maupun sosial, terutama terpenuhinya kebutuhan pokok anak. Undang-Undang Nomor 4 Tahun 1979 tentang Kesejahteraan Anak ini membedakan hak-hak seorang anak secara umum dan hak-hak anak secara khusus bagi anak-anak yang mengalami hambatan rohani, jasmani, sosial dan memerlukan pelayanan khusus. ${ }^{14}$

Ketentuan tersebut di atas diatur dalam Pasal 2 sampai dengan Pasal 8 Undang-Undang Nomor 4 Tahun 1979 tentang Kesejahteraan Anak, yang secara umum anak-anak berhak atas kesejahteraan, perawatan, asuhan, dan bimbingan berdasarkan kasih sayang, baik dalam keluarganya maupun di dalam asuhan khusus untuk tumbuh dan berkembang dengan wajar. Kesejahteraan dimaksud bukan saja diberikan pada waktu anak dilahirkan, tetapi juga pada saat dan semasa dalam kandungan. Semasa

13 Ibid.

14 Undang-Undang Nomor 4 Tahun 1979 tentang Kesejahteraan Anak. dalam masa kandungan maupun sesudah dilahirkan, anak berhak atas pelayanan untuk memgembangkan kemampuan dan kehidupan sosialnya, sesuai dengan kebudayaan dan kepribadian bangsa, untuk menjadi warga negara yang baik dan berguna. Terhadap lingkungan hidup yang dapat membahayakan atau menghambat pertumbuhan dan perkembangannya dengan wajar, anak berhak mendapat perlindungan. Bahkan anaklah yang pertama-tama berhak mendapat pertolongan, bantuan, dan perlindungan dalam keadaan yang membahayakan. ${ }^{15}$

\section{Tinjauan Undang-Undang terkait Anak sebagai Objek Kejahatan Pornografi}

Undang-Undang Pornografi Bab III (Perlindungan Anak) Pasal 15 menyebutkan Setiap orang berkewajiban melindungi anak dari pengaruh pornografi dan mencegah akses anak terhadap informasi pornografi. $^{16}$

Undang-Undang Pornografi Bab VII Ketentuan Pidana Pasal 37 berisi tentang Setiap orang yang melibatkan anak dalam kegiatan dan/atau sebagai objek sebagaimana dimaksud dalam Pasal 11 dipidana dengan pidana yang sama dengan pidana sebagaimana dimaksud dalam :

a. Pasal 29, yakni Setiap orang yang memproduksi, membuat, memperbanyak, menggandakan, menyebarluaskan, menyiarkan, mengimpor, mengekspor, menawarkan, memperjualbelikan, menyewakan, atau menyediakan

15 Rosnidar Sembiring. Hukum Keluarga : Harta-harta Benda dalam Perkawinan (Jakarta : Rajawali Pers, 2016), h.153-154 ${ }^{16}$ Ibid. 
pornografi Setiap orang yang memproduksi, membuat, memperbanyak, menggandakan, menyebarluaskan, menyiarkan, mengimpor, mengekspor, menawarkan, memperjualbelikan, menyewakan, atau menyediakan pornografi sebagaimana dimaksud dalam Pasal 4 ayat (1) dipidana dengan pidana penjara paling singkat 6 (enam) bulan dan paling lama 12 (dua belas) tahun dan/atau pidana denda paling sedikit Rp250.000.000,00 (dua ratus lima puluh juta rupiah) dan paling banyak Rp6.000.000.000,00 (enam miliar rupiah);

b. Pasal 30, yakni Setiap orang yang menyediakan jasa pornografi sebagaimana dimaksud dalam Pasal 4 ayat (2) dipidana dengan pidana penjara paling singkat 6 (enam) bulan dan paling lama 6 (enam) tahun dan/atau pidana denda paling sedikit Rp250.000.000,00 (dua ratus lima puluh juta rupiah) dan paling banyak Rp3.000.000.000,00 (tiga miliar rupiah);

c. Pasal 31, yakni Setiap orang yang meminjamkan atau mengunduh pornografi sebagaimana dimaksud dalam Pasal 5 dipidana dengan pidana penjara paling lama 4 (empat) tahun dan/atau pidana denda paling banyak Rp2.000.000.000,00 (dua miliar rupiah);

d. Pasal 32, yakni Setiap orang yang memperdengarkan,

mempertontonkan, memanfaatkan, memiliki, atau menyimpan produk pornografi sebagaimana dimaksud dalam Pasal 6 dipidana dengan pidana penjara paling lama 4 (empat) tahun dan/atau pidana denda paling banyak Rp2.000.000.000,00 (dua miliar rupiah);

e. Pasal 34, yakni Setiap orang yang dengan sengaja atau atas persetujuan dirinya menjadi objek atau model yang mengandung muatan pornografi sebagaimana dimaksud dalam Pasal 8 dipidana dengan pidana penjara paling lama 10 (sepuluh) tahun dan/atau pidana denda paling banyak Rp5.000.000.000,00 (lima miliar rupiah);

f. Pasal 35, yakni Setiap orang yang menjadikan orang lain sebagai objek atau model yang mengandung muatan pornografi sebagaimana dimaksud dalam Pasal 9 dipidana dengan pidana penjara paling singkat 1 (satu) tahun dan paling lama 12 (dua belas) tahun dan/atau pidana denda paling sedikit Rp500.000.000,00 (lima ratus juta rupiah) dan paling banyak Rp6.000.000.000,00 (enam miliar rupiah); dan

g. Pasal 36, yakni Setiap orang yang mempertontonkan diri atau orang lain dalam pertunjukan atau di muka umum yang menggambarkan ketelanjangan, eksploitasi seksual, persenggamaan, atau yang bermuatan pornografi lainnya sebagaimana dimaksud dalam Pasal 10 dipidana dengan pidana penjara paling lama 10 (sepuluh) tahun dan/atau pidana denda paling banyak Rp5.000.000.000,00 (lima miliar rupiah),

ditambah 1/3 (sepertiga) dari maksimum ancaman pidananya. ${ }^{17}$

Undang-Undang Pornografi Pasal 38 menyebutkan Setiap orang yang 
mengajak, membujuk, memanfaatkan, membiarkan, menyalahgunakan kekuasaan, atau memaksa anak dalam menggunakan produk atau jasa pornografi sebagaimana dimaksud dalam Pasal 12 dipidana dengan pidana penjara paling singkat 6 (enam) bulan dan paling lama 6 (enam) tahun dan/atau pidana denda paling sedikit Rp250.000.000,00 (dua ratus lima puluh juta rupiah) dan paling banyak Rp3.000.000.000,00 (tiga miliar rupiah). ${ }^{18}$

Undang-Undang Pornografi Pasal 39 menyebutkan Tindak pidana sebagaimana dimaksud dalam Pasal 29, Pasal 30, Pasal 31, Pasal 32, Pasal 33, Pasal 34, Pasal 35, Pasal 36, Pasal 37, dan Pasal 38 adalah kejahatan. ${ }^{19}$

Kitab Undang-Undang Hukum Pidana Buku Kesatu : Aturan Umum Bab IX Tentang Arti Beberapa Istilah Yang Dipakai Dalam Kitab UndangUndang Pasal 86 menyebutkan Apabila disebut kejahatan, baik dalam arti kejahatan pada umumnya maupun dalam arti suatu kejahatan tertentu, maka di situ termasuk pembantuan dan percobaan melakukan kejahatan, kecuali jika dinyatakan sebaliknya oleh suatu aturan. ${ }^{20}$

Undang-Undang

Republik

Indonesia Nomor 19 Tahun 2016 Tentang Perubahan Atas UndangUndang Nomor 11 Tahun 2008 Tentang Informasi dan Transaksi Elektronik (Undang-Undang Informasi dan Transaksi Elektronik) BAB VII (Perbuatan Yang Dilarang) Pasal 27 Ayat 1 menyebutkan Setiap Orang dengan sengaja dan tanpa hak mendistribusikan dan/atau

\footnotetext{
18 Ibid.

19 lbid.

20 Moeljatno, Kitab Undang-Undang Hukum Pidana (Jakarta : Bumi Aksara, 2016), h.36
}

mentransmisikan dan/atau membuat dapat diaksesnya Informasi Elektronik dan/atau Dokumen Elektronik yang memiliki muatan yang melanggar kesusilaan. Kemudian UndangUndang Informasi dan Transaksi Elektronik Bab XI (Ketentuan Pidana) Pasal 45 Ayat 1 menyebutkan juga bahwa Setiap Orang yang memenuhi unsur sebagaimana dimaksud dalam Pasal 27 ayat (1) dipidana dengan pidana penjara paling lama 6 (enam) tahun dan/atau denda paling banyak Rp1.000.000.000,00 (satu miliar rupiah). Di Pasal 52 Ayat 1 disebutkan Dalam hal tindak pidana sebagaimana dimaksud dalam Pasal 27 ayat (1) menyangkut kesusilaan atau eksploitasi seksual terhadap anak dikenakan pemberatan sepertiga dari pidana pokok. $^{21}$

Kitab Undang-Undang Hukum Pidana Buku Kesatu : Aturan Umum Bab III Tentang Hal-Hal yang Menghapuskan, Mengurangi atau Memberatkan Pidana Pasal 47 berisi tentang pengurangan pidana dapat diberikan jika penuntutan pidana dilakukan terhadap orang yang belum dewasa karena melakukan suatu perbuatan sebelum umur enam belas tahun. $^{22}$

Hal yang memperingan lainnya disebutkan di Kitab Undang-Undang Hukum Pidana Bab IV Tentang Percobaan Pasal 53 Ayat 2 yang menyebutkan maksimum pidana pokok terhadap kejahatan, dalam hal percobaan dapat dikurangi sepertiga. Selain itu, Bab V Tentang Penyertaan dalam Melakukan Perbuatan Pidana

\footnotetext{
${ }^{21}$ Undang-Undang Republik Indonesia Nomor 19 Tahun 2016 Tentang Perubahan Atas Undang-Undang Nomor 11 Tahun 2008 Tentang Informasi dan Transaksi Elektronik 22 Moeljatno, op.cit., h.23
} 
Pasal 57 Ayat 1 menyebutkan Dalam hal pembantuan, maksimum pidana pokok terhadap kejahatan, dikurangi sepertiga. Ayat 2 menyebutkan Jika kejahatan diancam dengan pidana mati atau pidana penjara seumur hidup, dijatuhkan pidana penjara paling lama lima belas tahun.

Kitab Undang-Undang Hukum Pidana Buku Kesatu (Aturan Umum) Bab VI Tentang Perbarengan (Concursus) Pasal 63 Ayat 1 menyebutkan Jika suatu perbuatan masuk dalam lebih dari satu aturan pidana, maka yang dikenakan hanya salah satu di antara aturan-aturan itu; jika berbeda-beda, yang dikenakan yang memuat ancaman pidana pokok yang paling berat. Kemudian di Ayat 2 pasal yang sama disebutkan Jika suatu perbuatan masuk dalam suatu aturan pidana yang umum, diatur pula dalam aturan pidana yang khusus, maka hanya yang khusus itulah yang diterapkan. Terkait hal ini, Undang-Undang Pornografi tidak mencantumkan pasal yang meringankan hukuman dalam Ketentuan Pidananya. ${ }^{23}$

Undang-Undang Pornografi Bab VII Ketentuan Pidana Pasal 37 berisi tentang Setiap orang yang melibatkan anak dalam kegiatan dan/atau sebagai objek sebagaimana dimaksud dalam Pasal 11 dipidana dengan pidana yang sama dengan pidana sebagaimana dimaksud dalam :

a. Pasal 29, yakni Setiap orang yang memproduksi, membuat, memperbanyak, menggandakan, menyebarluaskan, menyiarkan, mengimpor, mengekspor, menawarkan, memperjualbelikan, menyewakan, atau menyediakan pornografi Setiap orang yang

${ }^{23}$ Ibid., h.27 memproduksi, membuat, memperbanyak, menggandakan, menyebarluaskan, menyiarkan, mengimpor, mengekspor, menawarkan, memperjualbelikan, menyewakan, atau menyediakan pornografi sebagaimana dimaksud dalam Pasal 4 ayat (1) dipidana dengan pidana penjara paling singkat 6 (enam) bulan dan paling lama 12 (dua belas) tahun dan/atau pidana denda paling sedikit Rp250.000.000,00 (dua ratus lima puluh juta rupiah) dan paling banyak Rp6.000.000.000,00 (enam miliar rupiah);

b. Pasal 30, yakni Setiap orang yang menyediakan jasa pornografi sebagaimana dimaksud dalam Pasal 4 ayat (2) dipidana dengan pidana penjara paling singkat 6 (enam) bulan dan paling lama 6 (enam) tahun dan/atau pidana denda paling sedikit Rp250.000.000,00 (dua ratus lima puluh juta rupiah) dan paling banyak Rp3.000.000.000,00 (tiga miliar rupiah);

c. Pasal 31, yakni Setiap orang yang meminjamkan atau mengunduh pornografi sebagaimana dimaksud dalam Pasal 5 dipidana dengan pidana penjara paling lama 4 (empat) tahun dan/atau pidana denda paling banyak Rp2.000.000.000,00 (dua miliar rupiah);

d. Pasal 32, yakni Setiap orang yang memperdengarkan,

mempertontonkan, memanfaatkan, memiliki, atau menyimpan produk pornografi sebagaimana dimaksud dalam Pasal 6 dipidana dengan pidana penjara paling lama 4 (empat) tahun dan/atau pidana denda paling banyak 
Rp2.000.000.000,00 (dua miliar rupiah);

e. Pasal 34, yakni Setiap orang yang dengan sengaja atau atas persetujuan dirinya menjadi objek atau model yang mengandung muatan pornografi sebagaimana dimaksud dalam Pasal 8 dipidana dengan pidana penjara paling lama 10 (sepuluh) tahun dan/atau pidana denda paling banyak Rp5.000.000.000,00 (lima miliar rupiah);

f. Pasal 35, yakni Setiap orang yang menjadikan orang lain sebagai objek atau model yang mengandung muatan pornografi sebagaimana dimaksud dalam Pasal 9 dipidana dengan pidana penjara paling singkat 1 (satu) tahun dan paling lama 12 (dua belas) tahun dan/atau pidana denda paling sedikit Rp500.000.000,00 (lima ratus juta rupiah) dan paling banyak Rp6.000.000.000,00 (enam miliar rupiah); dan

g. Pasal 36, yakni Setiap orang yang mempertontonkan diri atau orang lain dalam pertunjukan atau di muka umum yang menggambarkan ketelanjangan, eksploitasi seksual, persenggamaan, atau yang bermuatan pornografi lainnya sebagaimana dimaksud dalam Pasal 10 dipidana dengan pidana penjara paling lama 10 (sepuluh) tahun dan/atau pidana denda paling banyak Rp5.000.000.000,00 (lima miliar rupiah),

ditambah $1 / 3$ (sepertiga) dari maksimum ancaman pidananya. ${ }^{24}$

Undang-Undang Pornografi Pasal 38 menyebutkan Setiap orang yang mengajak, membujuk, memanfaatkan,

24 Ibid. membiarkan, menyalahgunakan kekuasaan, atau memaksa anak dalam menggunakan produk atau jasa pornografi sebagaimana dimaksud dalam Pasal 12 dipidana dengan pidana penjara paling singkat 6 (enam) bulan dan paling lama 6 (enam) tahun dan/atau pidana denda paling sedikit Rp250.000.000,00 (dua ratus lima puluh juta rupiah) dan paling banyak Rp3.000.000.000,00 (tiga miliar rupiah). ${ }^{25}$

Undang-Undang Pornografi Pasal 39 menyebutkan Tindak pidana sebagaimana dimaksud dalam Pasal 29, Pasal 30, Pasal 31, Pasal 32, Pasal 33, Pasal 34, Pasal 35, Pasal 36, Pasal 37, dan Pasal 38 adalah kejahatan. ${ }^{26}$

Kitab Undang-Undang Hukum Pidana Buku Kesatu : Aturan Umum Bab IX Tentang Arti Beberapa Istilah Yang Dipakai Dalam Kitab UndangUndang Pasal 86 menyebutkan Apabila disebut kejahatan, baik dalam arti kejahatan pada umumnya maupun dalam arti suatu kejahatan tertentu, maka di situ termasuk pembantuan dan percobaan melakukan kejahatan, kecuali jika dinyatakan sebaliknya oleh suatu aturan. ${ }^{27}$

Undang-Undang Republik Indonesia Nomor 19 Tahun 2016 Tentang Perubahan Atas Undang-Undang Nomor 11 Tahun 2008 Tentang Informasi dan Transaksi Elektronik (Undang-Undang Informasi dan Transaksi Elektronik) BAB VII (Perbuatan Yang Dilarang) Pasal 27 Ayat 1 menyebutkan Setiap Orang dengan sengaja dan tanpa hak mendistribusikan dan/atau mentransmisikan dan/atau membuat

\footnotetext{
${ }^{25}$ lbid.

${ }^{26}$ Ibid.

27 Moeljatno, Kitab Undang-Undang Hukum Pidana (Jakarta : Bumi Aksara, 2016), h.36
} 
dapat diaksesnya Informasi Elektronik dan/atau Dokumen Elektronik yang memiliki muatan yang melanggar kesusilaan. Kemudian UndangUndang Informasi dan Transaksi Elektronik Bab XI (Ketentuan Pidana) Pasal 45 Ayat 1 menyebutkan juga bahwa Setiap Orang yang memenuhi unsur sebagaimana dimaksud dalam Pasal 27 ayat (1) dipidana dengan pidana penjara paling lama 6 (enam) tahun dan/atau denda paling banyak Rp1.000.000.000,00 (satu miliar rupiah). Di Pasal 52 Ayat 1 disebutkan Dalam hal tindak pidana sebagaimana dimaksud dalam Pasal 27 ayat (1) menyangkut kesusilaan atau eksploitasi seksual terhadap anak dikenakan pemberatan sepertiga dari pidana pokok. ${ }^{28}$

Kitab Undang-Undang Hukum Pidana Buku Kesatu : Aturan Umum Bab III Tentang Hal-Hal yang Menghapuskan, Mengurangi atau Memberatkan Pidana Pasal 47 berisi tentang pengurangan pidana dapat diberikan jika penuntutan pidana dilakukan terhadap orang yang belum dewasa karena melakukan suatu perbuatan sebelum umur enam belas tahun. $^{29}$

Hal yang memperingan lainnya disebutkan di Kitab Undang-Undang Hukum Pidana Bab IV Tentang Percobaan Pasal 53 Ayat 2 yang menyebutkan maksimum pidana pokok terhadap kejahatan, dalam hal percobaan dapat dikurangi sepertiga. Selain itu, Bab V Tentang Penyertaan dalam Melakukan Perbuatan Pidana Pasal 57 Ayat 1 menyebutkan Dalam

\footnotetext{
${ }^{28}$ Undang-Undang Republik Indonesia Nomor 19 Tahun 2016 Tentang Perubahan Atas Undang-Undang Nomor 11 Tahun 2008 Tentang Informasi dan Transaksi Elektronik

${ }^{29}$ Moeljatno, op.cit., h.23
}

hal pembantuan, maksimum pidana pokok terhadap kejahatan, dikurangi sepertiga. Ayat 2 menyebutkan Jika kejahatan diancam dengan pidana mati atau pidana penjara seumur hidup, dijatuhkan pidana penjara paling lama lima belas tahun.

Kitab Undang-Undang Hukum Pidana Buku Kesatu (Aturan Umum) Bab VI Tentang Perbarengan (Concursus) Pasal 63 Ayat 1 menyebutkan Jika suatu perbuatan masuk dalam lebih dari satu aturan pidana, maka yang dikenakan hanya salah satu di antara aturan-aturan itu; jika berbeda-beda, yang dikenakan yang memuat ancaman pidana pokok yang paling berat. Kemudian di Ayat 2 pasal yang sama disebutkan Jika suatu perbuatan masuk dalam suatu aturan pidana yang umum, diatur pula dalam aturan pidana yang khusus, maka hanya yang khusus itulah yang diterapkan. Terkait hal ini, Undang-Undang Pornografi tidak mencantumkan pasal yang meringankan hukuman dalam Ketentuan Pidananya. ${ }^{30}$

$\begin{array}{lrr}\text { PERLINDUNGAN } & \text { HUKUM } \\ \text { TERHADAP } & \text { ANAK } & \text { OBJEK } \\ \text { KEJAHATAN } & \text { PORNOGRAFI } \\ \text { ONLINE } & \text { BERDASARKAN } \\ \text { UNDANG-UNDANG } & \text { NOMOR 44 } \\ \text { TAHUN 2008 } & \text { TENTANG } \\ \text { PORNOGRAFI } & \end{array}$

Analisis Pasal-Pasal terkait Anak dalam Undang-Undang Nomor 44 Tahun 2008 Tentang Pornografi

Bagian awal Undang-Undang Pornografi telah menunjukan bahwa penetapan Undang-Undang tersebut mendasarkan pada semangat untuk

${ }^{30}$ Ibid., h.27 
memberikan perlindungan bagi anak. Hal ini dapat dilihat dari UndangUndang Pornografi diputuskan ditetapkan mengingat pada UndangUndang Dasar 1945 Pasal 28B ${ }^{31}$ yang salah satu intinya adalah menggarisbawahi bahwa setiap anak berhak atas perlindungan dari kekerasan.

Hal ini semakin terlihat pada Bab 1 Ketentuan Umum Undang-Undang Pornografi yang memberikan klasifikasi yang jelas bagi anak yakni seseorang yang belum berusia 18 (delapan belas) tahun. ${ }^{32}$ Klasifikasi ini penting karena memberikan batasan yang tegas klasifikasi usia anak sehingga tidak ada relativitas dalam kategori, karena terang disebutkan patokan usia yang dikategorikan anak. Penekanan pentingnya hak anak kembali ditekankan pada Pasal 2 mengenai tujuan Undang-Undang Pornografi yakni pada huruf d dengan terang menyebutkan memberikan kepastian hukum dan perlindungan bagi warga negara dari pornografi, terutama bagi anak dan perempuan. ${ }^{33}$ Pentingnya anak kembali digarisbawahi di dalam Bab 2 Undang-Undang Pornografi Pasal 4 Ayat 1 mengenai Larangan dan Pembatasan yang dengan jelas melarang pornografi anak sebagaimana disebutkan pada huruf $\mathrm{f}$ pasal tersebut. Hal ini dikuatkan dengan adanya pengulangan penekanan pada pasal-pasal berikutnya bahwa yang tercantum pada Pasal 4 Ayat 1 menjadi dasar larangan-larangan lainnya

\footnotetext{
31 Undang-Undang Dasar Negara Republik Indonesia Tahun 1945

32 Undang-Undang Republik Indonesia Nomor 44 Tahun 2008 Tentang Pornografi

${ }^{33}$ lbid.
}

sebagaimana yang disebutkan dalam Pasal 5, 6, 7, 8, 9, 10. ${ }^{34}$

Perhatian kepada anak semakin dipertegas di Pasal 11 UndangUndang Pornografi yang isinya melarang melibatkan anak dalam kegiatan dan/atau sebagai objek pornografi. Dilanjutkan dengan Pasal 12 yang berisi larangan mengajak, membujuk, memanfaatkan, membiarkan, menyalahgunakan kekuasaan atau memaksa anak dalam menggunakan produk atau jasa pornografi. $^{35}$

Perhatian yang besar mengenai perlindungan anak di dalam UndangUndang Pornografi semakin terlihat jelas dengan adanya Bab III yang judulnya adalah Perlindungan Anak. Di Pasal 15 Bab ini terang menncantumkan bahwa melindungi anak dari pengaruh pornografi dan mencegah akses anak terhadap informasi pornografi adalah kewajiban setiap orang $^{36}$, jadi perlindungan merupakan hak anak yang melekat menjadi tanggungan kewajiban setiap orang, siapapun itu.

Pelanggaran terkait tindakan pornografi anak sebagaimana tersebut di atas dengan serius diancam di dalam Undang-Undang Pornografi melalui Ketentuan Pidana yang tercantum di Bab VII Pasal 15 bahwa setiap orang yang melibatkan anak dalam kegiatan dan/atau sebagai objek tindakan pornografi anak dipidana dengan pidana yang sama baik pidana penjara dan/atau pidana denda sebagaimana dimaksud dalam pasal 29. 30, 31, 32, 34, 35 dan 36 dengan penekanan jika itu dilakukan dengan melibatkan anak maka ditambah 1/3

\footnotetext{
${ }^{34}$ Ibid

35 lbid.

36 lbid.
} 
(sepertiga) dari maksimum ancaman pidananya. $^{37}$ Dengan ini, dapat diartikan bahwa tindakan pornografi anak sanksinya adalah lebih berat karena ditambah sepertiga dari maksimum ancaman pidananya dibandingkan jika itu adalah tindakan pornografi bukan anak.

Pidana penjara yang dimaksudkan di atas sebelum ditambah sepertiga dari maksimum ancaman pidana bervariasi sesuai kategori pidananya, paling singkat 6 (enam) bulan hingga paling lama 12 (dua belas) tahun. Sedangkan untuk pidana denda, variasinya adalah paling sedikit Rp250.000.000,00 (dua ratus lima puluh juta rupiah) hingga paling banyak Rp6.000.000.000,00 (enam miliar rupiah).

Satu-satunya ketentuan pidana yang tidak mencantumkan bahwa pelanggaran tersebut sanksinya tidak ditambah sepertiga dari maksimum ancaman pidana adalah jika pelanggarannya dalam bentuk melibatkan anak dalam menggunakan produk atau jasa pornografi. Hal ini disebutkan dalam Pasal 38 UndangUndang Pornografi. Pidananya adalah pidana penjara paling singkat 6 (enam) bulan dan paling lama 6 (enam) tahun sedangkan pidana dendanya Rp250.000.000,00 (dua ratus lima puluh juta rupiah) dan paling banyak Rp6.000.000.000,00 (enam miliar rupiah). ${ }^{38}$

Penegasan bahwa tindakan melibatkan anak dalam pornografi adalah kejahatan terang disebutkan pada Pasal 39. ${ }^{39}$

\section{Analisis Perlindungan Hukum Anak dalam Undang-Undang}

37 Ibid.

38 lbid.

39 lbid.

\section{Nomor 44 Tahun 2008 Tentang Pornografi berdasarkan Teori Hukum}

Dapat dikatakan bahwa UndangUndang Pornografi ditetapkan untuk mengadakan keseimbangan dalam masyarakat dimana di satu sisi anak memiliki akses terhadap informasi namun mesti diatur juga mengenai haknya untuk mendapatkan perlindungan. Hal ini berdasar pada Undang-Undang Pornografi yang merujuk pada Undang-Undang Dasar 1945 yang menyebutkan tentang hak anak untuk mendapatkan perlindungan. Dengan kata lain, Undang-Undang Pornografi merupakan turunan atau penguat Undang-Undang Dasar 1945 untuk memastikan anak mendapatkan hak perlindungannya.

Mengenai keseimbangan tersebut di atas, sesuai dengan pandangan Roscoe Pound yang menyatakan hukum bukan hanya merupakan kumpulan norma-norma abstrak atau suatu tertib hukum, tetapi juga merupakan suatu proses (process) untuk mengadakan keseimbangan antara kepentingankepentingan dan nilai-nilai yang saling bertentangan. Proses itu pada akhirnya melahirkan keseimbangankeseimbangan baru membuat masyarakat terekayasa menuju keadaan baru yang lebih baik dengan keseimbangan-keseimbangan baru. ${ }^{40}$ Hal tersebut di atas serupa dengan beberapa pengertian hak, karena kepentingan anak dilindungi oleh Undang-Undang Pornografi. Melalui Undang-Undang Pornografi, maka tata hukum memberikan kepada anak haknya, yakni hak kepentingan mendapatkan perlindungan hukum

\footnotetext{
40 Donald Albert Rumokoy, \& Frans Marantis, op.cit., h.36-37
} 
atau kuasa untuk mendapatkan perlindungan hukum. Beberapa pengertian hak yang dimaksudkan adalah $^{41}$ sesuai dengan pengertian hak menurut Rudolf von Ihering (hak adalah kepentingan yang dilindungi oleh hukum, Bernhard Windscheid (hak adalah kekuasaan yang diberikan oleh tata hukum), dan menurut L.J. van Apeldoorn (dalam kepentingan yang dilindungi oleh hukum terkandung kekuasaan karena perlindungan berarti kekuasaan; sedangkan dalam kekuasaan yang diberikan oleh hukum terkandung unsur kepentingan karena kekuasaan diberikan untuk melindungi kepentingan. Jadi hak adalah kepentingan dan juga kekuasaan).

Sebagaimana Undang-Undang mengatur mengenai larangan, maka untuk kepentingan pencegahan atau pemberian sanksi, Undang-Undang mesti mengaturnya. Hal ini sesuai dengan pendapat Backy Krisnayudha yang menyebutkan aturan Negara harus ada ketentuan hukum yang mengaturnya; harus ada hak dan kewajiban yang diberikan oleh hukum tersebut; harus ada tata cara pelaksanaannya; dan harus ada sanksinya. $^{42}$ Begitu pula UndangUndang Pornografi, yang tidak hanya mengatur mengenai larangan-larangan namun juga mencantumkan dengan jelas sanksi (ketentuan pidana) yang akan diberikan jika larangan itu dilanggar oleh pelaku.

Jika dikaji dari ketentuan pidana, Undang-Undang Pornografi memberikan pilihan kepada hakim untuk menentukan lama waktu pidana penjara dan jumlah besaran pidana

${ }^{41}$ Ibid., h. 123

42 Backy Krisnayudha, op.cit., h.30 denda, meskipun nilai paling singkat atau paling lama untuk pidana penjara dan paling kecil dan paling besar untuk pidana denda tetap ditentukan. Dalam hal ini jawaban terhadap permasalahan praktis bagaimana anak dilindungi masih diserahkan secara lebih lanjut ke hakim. Hal ini sepertinya berdasarkan pemikiran Montesquieu yang menyatakan bahwa hakim mesti berfungsi sebagai corong undang-undang atau menerjemahkan undang-undang dan sebagai orang baik yang menilai dari sudut keadilan. ${ }^{43}$

Pentingnya putusan hakim karena hal tersebut akan menjadi preseden seperti yang disampaikan Paul Scholten bahwa setiap putusan hakim, sebagai unsur yang mandiri selalu menemukan sesuatu yang baru ${ }^{44}$, sehingga berapa lama masa pidana penjara dan berapa besar denda akan menjadi rujukan jika tindak pidana pornografi terjadi lagi, maka putusan sebelumnya dapat menjadi acuan (menimbulkan sesuatu yang baru). Apalagi jika pemikiran Muller ${ }^{45}$ dipertegas di sini dimana pencegahan untuk berulangnya kejadian serupa ada di penentuan pidana oleh hakim, bukan di eksekusi pidana atau ancaman pidana.

Dapat dikatakan oleh karena UndangUndang Pornografi tidak mencantumkan tapi memberikan pilihan kepada hakim, maka hakim mesti meninjau jika ada hal yang mampu meringankan terdakwa. Meninjau hal ini, mesti mengacu kepada Ketentuan dalam Kitab Undang-Undang Hukum Pidana Bab

\footnotetext{
43 Philipus M. Hadjon \& Tatiek Sri Djatmiati, op.cit, h.24

44 lbid, h.25

${ }^{45}$ Andi Hamzah, op.cit, h.30
} 
III Pasal $47^{46}$ dan atau Bab IV Pasal 53 Ayat $2^{47}$ dan atau Bab V Pasal 57 Ayat $1^{48}$. Pasal 47 menyatakan bahwa hal yang meringankan adalah jika terdakwa belum berusia enam belas tahun. Lebih dari usia itu maka tidak ada disebutkan mengenai adanya keringanan terhadap terdakwa, apalagi jika dakwaan menyangkut pornografi anak kecuali dalam hal terkait menyebabkan anak menggunakan produk atau jasa pornografi, maka mesti diberikan tambahan hukuman sepertiga dari maksimum ancaman pidananya.

Selain dari batasan tersebut dalam Pasal 47 Kitab Undang-Undang Hukum Pidana, peringan lainnya yakni sebagaimana tercantum dalam Pasal 53 Ayat 2 menyebutkan mengenai percobaan. Jadi jika terdakwa baru sampai tahap percobaan melakukan tindak pidana, baru peringanan hukuman dapat diberikan.

Peringan lainnya yang disebutkan dalam Pasal 57 Ayat 1 Kitab UndangUndang Hukum Pidana menyebutkan jika tindakan yang dilakukan adalah pembantuan melakukan kejahatan, baru dapat diperingan hukumannya. Selain dari ketiga hal tersebut ini, karena di dalam Undang-Undang Pornografi tidak menyebutkan apa yang dapat memperingan hukuman, maka tidak ada hal lain yang dapat meringankan secara yuridis.

Mengenai ketentuan sepertiga dari maksimum ancaman pidana ini, Undang-Undang Pornografi memberikan kemudahan bagi hakim dalam menetapkan putusan pidana sesuai fungsi melindungi anak sesuai

${ }^{46}$ Moeljatno, op.cit., h.23

47 lbid, h.25

48 Ibid, h.26
Undang-Undang Pornografi karena tegas disebutkan hal tersebut. Pemberian tambahan hukuman sepertiga dari maksimum ancaman pidana menunjukkan bahwa sengaja ditekankan oleh Undang-Undang Pornografi bahwa bagi yang berniat melakukan kejahatan pornografi anak, maka akan disanksi lebih berat. Dalam hal ini, Undang-Undang Pornografi ditunjukkan sebagai pelindung bagi anak. Hal ini sesuai dengan pendapat Van Hamel yang menunjukkan bahwa prevensi khusus suatu pidana salah satunya adalah harus memuat suatu unsur menakutkan supaya mencegah penjahat yang mempunyai kesempatan untuk tidak melaksanakan niat buruknya. ${ }^{49}$ Dapat dikatakan bahwa Undang-Undang Pornografi ditetapkan dengan niat untuk memastikan pemenjaraan yang singkat tidak terjadi bagi para pelaku kejahatan pornografi kecuali dalam hal terkait menyebabkan anak menggunakan produk atau jasa pornografi yang tidak menyebutkan adanya tambahan hukuman sepertiga dari ancaman pidana maksimum. Dalam hal tambahan hukuman tersebut, Undang-Undang Pornografi menunjukkan supaya mencegah penjahat atau calon penjahat yang mempunyai kesempatan untuk tidak melaksanakan niat buruknya, ada upaya untuk memuat suatu unsur menakutkan. Dengan adanya unsur menakutkan tersebut, diharapkan dapat mencegah kejahatan pornografi terhadap anak baik online maupun non online sehingga hak anak terlindungi.

${ }^{49}$ Andi Hamzah, op.cit., h.36 
PENERAPAN HUKUM TERKAIT KEJAHATAN PORNOGRAFI ONLINE YANG MENJADIKAN ANAK SEBAGAI OBJEK DALAM PUTUSAN NOMOR 1363/PID.SUS/2017/PN JKT.SEL BERDASARKAN UNDANGUNDANG NOMOR 44 TAHUN 2008 TENTANG PORNOGRAFI

\section{Ringkasan Putusan Nomor 1363/Pid.Sus/2017/PN JKT. SEL}

Pada hari Rabu, tanggal 14 Februari 2018, Sidang Permusyawaratan Majelis Hakim Pengadilan Negeri Jakarta Selatan terdiri dari Akhmad Jaini, S.H..,M.H, sebagai Hakim Ketua, Riyadi Sunindyo Florentinus, S.H., Lenny Wati Mulasimadhi, S.H..MH masing-masing sebagai Hakim Anggota memutuskan mengadili menyatakan Terdakwa Yulianto Bin Suwoto telah terbukti secara sah dan meyakinkan bersalah melakukan tindak pidana "tanpa hak atau melawan hukum, menyebarluaskan Informasi Elektronik dan/atau Dokumen Elektronik yang memiliki muatan yang melanggar kesusilaan dan memperjualbelikan pornografi anak". Saat persidangan, terdakwa menghadap Pengadilan tanpa didampingi oleh Penasihat Hukum dan hanya memohon keringanan hukuman. Tuntutan Penuntut Umum yakni pidana penjara selama 3 (tiga) tahun dan pidana denda sebesar Rp.1.000.000.000,00 (satu milyar rupiah), jika tidak dibayar diganti dengan penjara selama 6 (enam) bulan.

Mendengar permohonan terdakwa, Penuntut Umum tetap pada tuntutannya. Terdakwa setelah mendengarkan tanggapan Penuntut
Umum, juga tetap pada permohonannya yakni memohon keringanan hukuman.

Pidana dijatuhkan terhadap Terdakwa dengan mempertimbangkan keadaan yang memberatkan dan yang meringankan Terdakwa :

1. Keadaan yang memberatkan:

- Perbuatan terdakwa dapat merusak moral dan ahlak generasi muda

- Perbuatan terdakwa dapat merusak masa depan generasi muda bangsa;

2. Keadaan yang meringankan:

- Terdakwa mengakui terus terang perbuatannya dan berjanji tidak akan mengulanginya lagi

- Terdakwa masih muda dan diharapkan dapat memperbaiki kesalahannya dimasa mendatang

- Terdakwa belum pernah dihukum

Pertimbangan-pertimbangan lain untuk menjatuhkan putusan sebagai berikut ;

1. Terdakwa tanpa hak atau melawan hukum dengan sengaja dan tanpa hak mendistribusikan dan/atau mentransmisikan dan/atau membuat dapat diaksesnya Informasi Elektronik dan/atau Dokumen Elektronik yang memiliki muatan yang melanggar kesusilaan;

2. terdakwa tanpa hak atau melawan hukum dengan sengaja dan tanpa hak mendistribusikan dan/atau mentransmisikan dan/atau membuat dapat diaksesnya Informasi Elektronik dan/atau Dokumen Elektronik yang memiliki muatan yang melanggar kesusilaan atau pornografi anak sebagaimana dimaksud dalam Pasal 29 juncto Pasal 4 Ayat 1 
huruf f Undang-Undang Republik Indonesia Nomor 44 Tahun 2008 Tentang Pornografi;

3. terdakwa memohon kepada Majelis Hakim untuk kiranya menjatuhkan hukuman yang seringan-ringannya bagi Terdakwa, Majelis Hakim menyatakan akan mempertimbangkan hal-hal yang meringankan terdakwa;

4. oleh karena selama pemeriksaan di persidangan Majelis tidak menemukan adanya alasan pemaaf dan alasan pembenar pada diri dan perbuatan Terdakwa, maka Terdakwa harus dinyatakan bersalah atas perbuatannya yang telah dinyatakan terbukti tersebut sehingga untuk itu, Terdakwa harus dijatuhi pidana;

5. oleh karena ancaman pidana yang diatur dalam Undang-Undang Republik Indonesia Nomor 19 Tahun 2016 tentang Perubahan atas Undang-Undang Republik Indonesia Nomor 11 Tahun 2008 Tentang Informasi dan Transaksi Elektronik dan Undang-Undang Republik Indonesia Nomor 44 Tahun 2008 Tentang Pornografi bersifat kumulatif yaitu berupa pidana penjara dan pidana denda, maka kepada Terdakwa disamping harus dijatuhkan pidana badan berupa pidana penjara harus pula dijatuhkan pidana denda.

Putusan dijatuhkan setelah memperhatikan Pasal 27 ayat 1 Juncto Pasal 45 ayat 1 Juncto Pasal 52 ayat 1 Undang-Undang Republik Indonesia Nomor 19 Tahun 2016 tentang Perubahan atas UndangUndang Republik Indonesia Nomor 11 Tahun 2008 Tentang Informasi dan Transaksi Elektronik dan Pasal 29 juncto Pasal 4 ayat 1 huruf f Undang-
Undang Republik Indonesia Nomor 44 Tahun 2008 Tentang Pornografi dan Undang-undang Nomor 8 Tahun 1981 tentang Hukum Acara Pidana serta peraturan perundang-undangan lain yang bersangkutan.

Putusan tersebut diucapkan dalam sidang terbuka untuk umum pada hari dan tanggal itu juga oleh Hakim Ketua dengan didampingi para Hakim Anggota tersebut, dibantu oleh Nurlelawati, SH., MH,, Panitera Pengganti pada Pengadilan Negeri Jakarta Selatan, serta dihadiri oleh Marshel Julia Simbiak, S.H.., M.H., Penuntut Umum dan Terdakwa Hakim.

Terdakwa dalam amar putusan tersebut dijatuhi pidana penjara selama 2 (dua) tahun dan denda sebesar Rp.1.000.000.000,00 (satu milyar rupiah) dengan ketentuan jika denda tersebut tidak dibayar, diganti dengan pidana kurungan selama 3 (tiga) bulan. Putusan yang dijatuhkan oleh Majelis Hakim lebih ringan daripada tuntutan Penuntut Umum.

Dalam amar putusan tidak disebutkan bahwa terdakwa dijatuhi pemberatan sepertiga dari ancaman hukuman maksimum, baik untuk pidana penjara maupun pidana denda. Pun tidak disebutkan bahwa terdakwa hanya melakukan percobaan tindak pidana atau pembantuan terjadinya tindak pidana.

\section{Analisis Pertimbangan Majelis Hakim}

Dalam menjatuhkan putusan pidana, Majelis Hakim menyebutkan mempertimbangkan keadaan yang memberatkan maupun keadaan yang meringankan. Menurut Majelis Hakim, yang memberatkan terdakwa adalah perbuatan terdakwa dapat 
merusak moral dan ahlak generasi muda dan dapat merusak masa depan generasi muda bangsa.

Dalam pertimbangan tersebut, dapat diartikan Majelis Hakim menekankan pentingnya putusan dijatuhkan karena tindakan ybs dapat berakibat buruk bagi generasi muda bangsa. Merujuk pada pasal yang digunakan untuk rujukan bagi putusan, dapat diartikan perhatian Majelis Hakim tertuju pada Undang-Undang Pornografi. Dalam hal ini, Majelis Hakim menempatkan Undang-Undang Pornografi sebagai inti pertimbangan menjerat pelaku dalam putusannya sedangkan UndangUndang Informasi dan Transaksi Elektronik untuk menjerat cara si terdakwa melakukan perbuatan melawan hukumnya.

Berdasar dari pertimbangan yang disebutkan dalam putusan tersebut, dapat diartikan Majelis Hakim merujuk pada salah satu tujuan Undang-Undang Pornografi yakni yang tercantum di Pasal 3 huruf $d$ yakni memberikan kepastian hukum dan perlindungan bagi anak. ${ }^{50} \mathrm{Hal}$ ini senada pula dengan Undang-Undang Pornografi Bab III (Perlindungan Anak) Pasal 15 yang menyebutkan setiap orang berkewajiban melindungi anak dari pengaruh pornografi ${ }^{51}$ dimana hal ini sesuai dengan pendapat Roscoe Pound yang tidak menunjuk pihak tertentu sebagai yang paling berjasa untuk merekayasa masyarakat menuju keseimbangankeseimbangan yang baru. Dengan demikian, semua pihak, baik anggota masyarakat yang melakukan unjuk rasa, mass media yang membentuk pendapat umum (public opinion),

50 Undang-Undang Nomor 44 Tahun 2008 Tentang Pornografi

${ }^{51}$ lbid. hakim yang menjatuhkan putusan dalam hal suatu perkara dibawa ke pengadilan, maupun pemerintah yang membuat peraturan perundangundangan, memiliki perannya masingmasing dalam melahirkan keseimbangan-keseimbangan yang baru tersebut. ${ }^{52}$

Kemudian apa yang meringankan menurut Majelis Hakim adalah terdakwa mengakui terus terang perbuatannya, berjanji tidak akan mengulanginya, masih muda dan diharapkan dapat memperbaiki kesalahan di masa mendatang dan belum pernah dihukum. Jika mengacu kepada Ketentuan Kitab UndangUndang Hukum Pidana, tidak ada salah satu dari hal di atas secara yuridis yang dapat dijadikan peringan hukuman, karena seperti disebut di dalam Pasal 47 Kitab Undang-Undang Hukum Pidana, hal yang mampu meringankan adalah jika terdakwa belum berusia 16 (enam belas) tahun ${ }^{53}$ tidak ada dalam fakta yang diuraikan di persidangan. Jelas disebutkan bahwa terdakwa berusia 19 (sembilan belas) tahun.

Hal lain yang dapat memperingan hukuman yakni seperti disebutkan di Pasal 53 Ayat 2 Kitab UndangUndang Hukum Pidana yakni terdakwa melakukan percobaan kejahatan. ${ }^{54}$ Hal ini juga tidak ada disebutkan dalam putusan karena dalam amar putusan menyebutkan terdakwa melakukan tindak pidana melawan hukum menyebarluaskan dan memperjualbelikan pornografi anak, bukan melakukan percobaan menyebarluaskan dan atau

\footnotetext{
52 Donald Albert Rumokoy \& Frans Marantis, Ibid., h.36-37

${ }^{53}$ Moeljatno, op.cit., h. 22

54 Ibid, h.25
} 
memperjualbelikan pornografi anak. Dengan demikian, peringan hukuman sebagaimana tercantum dalam Pasal 53 Ayat 2 Kitab Undang-Undang Hukum Pidana juga dapat diartikan tidak berpengaruh dalam penetapan putusan tersebut.

Hal berikutnya yang dapat meringankan yakni sebagaimana tercantum dalam Kitab UndangUndang Hukum Pidana Pasal 57 Ayat $1^{55}$ yakni dalam hal pembantuan maka pidananya diperingan, melihat ke putusan perkara tersebut tidak juga menyebutkan bahwa terdakwa hanya melakukan perbuatan pembantuan terjadinya tindak pidana, sehingga peringan hukuman berdasar dari Pasal 57 Ayat 1 pun dapat diartikan tidak mempengaruhi pertimbangan Majelis Hakim dalam memperingan penetapan putusan tersebut.

Dalam hal yang meringankan tersebut, dapat diartikan Majelis Hakim meringankan pidana berdasar pertimbangan non yuridis dari Majelis Hakim sendiri. Hal ini dimungkinkan karena saat persidangan, terdakwa memohon keringanan hukuman, sehingga meskipun Penuntut Umum menuntut terdakwa dijatuhi pidana penjara 3 (tiga) tahun dan pidana denda Rp1.000.000.000,00 (1 miliar rupiah), Majelis Hakim menjatuhkan pidana di bawah tuntutan Penuntut Umum pada pidana penjara namun mengabulkan tuntutan Penuntut Umum pada pidana denda.

\section{Analisis Putusan}

Majelis Hakim menyebutkan menjatuhkan putusannya dengan memperhatikan Undang-Undang Informasi dan Transaksi Elektronik

55 lbid., h.26 dan Undang-Undang Pornografi dimana Pasal yang digunakan untuk menjerat terdakwa pada UndangUndang Pornografi adalah Pasal 4 Ayat 1 Huruf $\mathrm{f}^{56}$ yang menyebutkan Setiap orang dilarang memproduksi, membuat, memperbanyak, menggandakan, menyebarluaskan, menyiarkan, mengimpor, mengekspor, menawarkan, memperjualbelikan, menyewakan, atau menyediakan pornografi yang secara eksplisit memuat pornografi anak.

Ketentuan pidana untuk kejahatan pornografi tercantum pada Pasal 4 Ayat 1 Huruf $f$ bergantung pada tindakannya. Dalam Putusan disebutkan tindakan terdakwa adalah menyebarluaskan dan memperjualbelikan, sehingga mesti merujuk pada Pasal 29 UndangUndang Pornografi yang berbunyi Setiap orang yang memproduksi, membuat, memperbanyak, menggandakan, menyebarluaskan, menyiarkan, mengimpor, mengekspor, menawarkan, memperjualbelikan, menyewakan, atau menyediakan pornografi sebagaimana dimaksud dalam Pasal 4 ayat (1) dipidana dengan pidana penjara paling singkat 6 (enam) bulan dan paling lama 12 (dua belas) tahun dan/atau pidana denda paling sedikit Rp250.000.000,00 (dua ratus lima puluh juta rupiah) dan paling banyak Rp6.000.000.000,00 (enam miliar rupiah) ${ }^{57}$ sehingga terdakwa mesti dijatuhi pidana penjara paling singkat 6 (enam) bulan dan paling lama 12 (dua belas) tahun dan/atau pidana denda paling sedikit Rp250.000.000,00 (dua ratus lima

\footnotetext{
56 Undang-Undang Nomor 44 Tahun 2008 Tentang Pornografi ${ }^{57}$ lbid.
} 
puluh juta rupiah) dan paling banyak Rp6.000.000.000,00 (enam miliar rupiah). Dan mesti ditambahkan sepertiga dari ancaman hukuman maksimum berdasarkan Pasal $37^{58}$ Undang-Undang Pornografi yang menyebutkan Setiap orang yang melibatkan anak dalam kegiatan dan/atau sebagai objek sebagaimana dimaksud dalam Pasal 11 dipidana dengan pidana yang sama dengan pidana sebagaimana dimaksud dalam salah satunya Pasal 29 tersebut di atas dan ditambah 1/3 (sepertiga) dari maksimum ancaman pidananya.

Jika diasumsikan pidana penjara paling rendah adalah 6 (enam) bulan dan Rp250.000.000,00 (dua ratus lima puluh juta rupiah), maka hakim dapat menjatuhkan pidana penjara paling rendah 6 (enam) bulan ditambah 4 (empat) tahun (sepertiga dari ancaman hukuman maksimum 12 tahun), total 4 (empat) tahun 6 (enam) bulan. Dapat diartikan putusan pidana penjara yang dijatuhkan Majelis Hakim yakni 2 tahun tidak mengacu kepada Undang-Undang Pornografi.

Kemudian mengenai pidana denda jika diasumsikan paling rendah adalah Rp250.000.000,00 (dua ratus lima puluh juta rupiah), maka hakim dapat menjatuhkan pidana denda paling rendah Rp250.000.000,00 (dua ratus lima puluh juta rupiah) ditambah Rp2.000.000.000,00 (dua miliar rupiah) yang merupakan sepertiga dari ancaman hukuman maksimum Rp6.000.000.000,00 (enam miliar rupiah), total $\mathrm{Rp} 2.250 .000 .000,00$ (dua miliar dua ratus lima puluh juta rupiah). Dapat diartikan putusan pidana denda yang dijatuhkan majelis hakim yakni Rp1.000.000.000,00

58 lbid. (satu miliar rupiah) tidak mengacu kepada Undang-Undang Pornografi.

Merujuk pada kedua hal tersebut di atas, dapat dikatakan bahwa Majelis Hakim pada perkara tersebut tidak mengacu kepada ketentuan minimum pidana penjara dan pidana denda yang tercantum pada Undang-Undang Pornografi padahal Majelis Hakim dengan jelas menyebut bahwa perbuatan melawan hukum terdakwa adalah bentuk pelanggaran yang sanksinya adalah sebagaimana tercantum pada Pasal 29 UndangUndang Pornografi. Berbeda jika Majelis Hakim menyebutkan pelanggaran tersebut sanksinya adalah sesuai yang tercantum di Pasal 38 Undang-Undang Pornografi yang berbunyi Setiap orang yang mengajak, membujuk, memanfaatkan, membiarkan, menyalahgunakan kekuasaan, atau memaksa anak dalam menggunakan produk atau jasa pornografi sebagaimana dimaksud dalam Pasal 12 dipidana dengan pidana penjara paling singkat 6 (enam) bulan dan paling lama 6 (enam) tahun dan/atau pidana denda paling sedikit Rp250.000.000,00 (dua ratus lima puluh juta rupiah) dan paling banyak Rp3.000.000.000,00 (tiga miliar rupiah). Jika yang dicantumkan oleh Majelis Hakim adalah Pasal 38 maka terdakwa dapat diputus pidana penjara paling singkat 6 (enam) bulan dan pidana denda paling sedikit Rp250.000.000,00 (dua ratus lima puluh juta rupiah) serta tidak dikenakan pemberatan sepertiga dari maksimum ancaman pidananya.

Jika menurut Majelis Hakim, terdakwa mesti diringankan hukumannya dari yang semestinya pidana penjara 4 (empat) tahun 6 (enam) bulan dan pidana denda 
Rp2.250.000.000,00 (dua miliar dua ratus lima puluh juta rupiah), maka merujuk pada Kitab Undang-Undang Hukum Pidana, ada 3 (tiga) hal yang secara yuridis dapat meringankan pidana, yakni usia pelaku belum 16 (enam belas) tahun, tindak pidana yang dilakukan bersifat percobaan, dan tindak pidana yang dilakukan bersifat pembantuan.

Dalam hal yang dapat meringankan adalah jika penuntutan dilakukan terhadap seorang yang belum berusia 16 (enam belas) tahun. Karena dalam perkara tersebut terdakwa sudah berusia 19 (Sembilan belas) tahun maka keringanan hukuman semestinya tidak diberikan kepada terdakwa. Hal ini semestinya merujuk pada Kitab Undang-Undang Hukum Pidana Buku Kesatu : Aturan Umum Bab III Tentang Hal-Hal yang Menghapuskan, Mengurangi atau Memberatkan Pidana Pasal 47 berisi tentang pengurangan pidana dapat diberikan jika penuntutan pidana dilakukan terhadap orang yang belum dewasa karena melakukan suatu perbuatan sebelum umur enam belas tahun.

Dalam hal yang dapat meringankan adalah tindak pidana bersifat percobaan, telah terang disebutkan bahwa terdakwa telah menyebarluaskan dan memperjualbelikan sehingga alasan peringan ini tidak dapat digunakan, maka keringanan hukuman semestinya tidak diberikan kepada terdakwa. Hal ini semestinya merujuk pada Kitab Undang-Undang Hukum Pidana Bab IV Tentang Percobaan Pasal 53 Ayat 2 yang menyebutkan maksimum pidana pokok terhadap kejahatan, dalam hal percobaan dapat dikurangi sepertiga, dimana jika hal tersebut sifatnya bukan percobaan maka peringan hukuman dengan alasan percobaan tidak dapat diberikan.

Dalam hal yang dapat meringankan adalah tindak pidana bersifat pembantuan, telah terang disebutkan bahwa terdakwa adalah pelaku yang menyebarluaskan dan memperjualbelikan sehingga alasan peringan pembantuan juga tidak dapat digunakan, maka keringanan hukuman semestinya tidak diberikan kepada terdakwa. Hal ini semestinya merujuk kepada Selain itu, Bab V Tentang Penyertaan dalam Melakukan Perbuatan Pidana Pasal 57 Ayat 1 menyebutkan Dalam hal pembantuan, maksimum pidana pokok terhadap kejahatan, dikurangi sepertiga, namun karena yang dilakukan bukan pembantuan, namun terdakwa melakukan perbuatannya sendiri maka peringan hukuman dengan alasan pembantuan tidak dapat diberikan.

Mencermati amar putusan yang juga menyebutkan bahwa perbuatan melawan hukum terdakwa dijatuhi pidana karena melanggar UndangUndang Informasi dan Transaksi Elektronik, ternyata setelah ditinjau di dalam Undang-Undang Informasi dan Transaksi Elektronik, dapat diartikan Majelis Hakim dalam menjatuhkan putusan lebih cenderung merujuk pada Pasal 45 Ayat 1 Undang-Undang Informasi dan Transaksi Elektronik dikarenakan tidak adanya ketentuan pidana penjara paling singkat dan pidana denda paling rendah, namun hanya menyebutkan maksimum ancaman pidana penjara paling lama 6 (enam) tahun dan pidana denda paling banyak Rp1.000.000.000,00 (satu miliar rupiah). 
Sehingga dapat dikatakan penjatuhan pidana terhadap terdakwa yakni 2 (dua) tahun lebih mengacu kepada Undang-Undang Informasi dan Transaksi Elektronik. Namun jika menelisik lebih detail bahwa amar putusan juga menyebutkan terdakwa melanggar Pasal 52 Ayat 1 UndangUndang Informasi dan Transaksi Elektronik yang menyebutkan tindak pidana tersebut dikenakan pemberatan sepertiga dari pidana pokok, sedangkan di putusan pidana penjara dan pidana denda tidak ada disebutkan rinci adanya pemberatan sepertiga dari pidana pokok, maka tidak dapat diasumsikan begitu saja bahwa Majelis Hakim telah mempertimbangkan ketentuan Pasal 52 Ayat 1 Undang-Undang Informasi dan Transaksi Elektronik telah digunakan untuk memperhitungkan pidana penjara dan pidana denda bagi terdakwa.

Tidak dijadikannya Undang-Undang Pornografi sebagai acuan penetapan pidana penjara dan pidana denda bagi terdakwa menjadi hal yang bisa dicermati mengingat ketentuan Kitab Undang-Undang Hukum Pidana Pasal 63 Ayat 1 menyebutkan bahwa jika ada aturan yang berbeda, maka yang dikenakan adalah ancaman pidana pokok yang paling berat. Dalam perkara tersebut, Undang-Undang Pornografi ancaman pidana pokoknya baik pidana penjara maupun pidana denda lebih berat dibanding ancaman pidana pokok di Undang-Undang Informasi dan Transaksi Elektronik, jadi dapat diartikan semestinya yang digunakan adalah ketentuan pidana di dalam Undang-Undang Pornografi. Hal ini semestinya merujuk pada Kitab Undang-Undang Hukum Pidana Buku Kesatu (Aturan Umum) Bab VI
Tentang Perbarengan (Concursus) Pasal 63 Ayat 1 menyebutkan Jika suatu perbuatan masuk dalam lebih dari satu aturan pidana, maka yang dikenakan hanya salah satu di antara aturan-aturan itu; jika berbeda-beda, yang dikenakan yang memuat ancaman pidana pokok yang paling berat. Kemudian di Ayat 2 pasal yang sama disebutkan Jika suatu perbuatan masuk dalam suatu aturan pidana yang umum, diatur pula dalam aturan pidana yang khusus, maka hanya yang khusus itulah yang diterapkan. Jadi semestinya yang dijadikan acuan penetapan acuan mestinya adalah Undang-Undang Pornografi.

Tidak dijadikannya Undang-Undang Pornografi sebagai acuan yuridis utama dalam putusan tersebut sehingga tidak diberikan pula sanksi yang lebih berat dalam putusan perkara tersebut dapat diartikan bahwa putusan yang ditetapkan oleh Majelis Hakim tidak sejalan dengan pendapat mengenai langkah rechtsvinding (upaya memberikan jawaban yang jelas terhadap persoalan hukum praktis) dimana menurut Neil MacCormick, hampir setiap peraturan hukum menunjukkan hubungan yang membingungkan dan tidak jelas dalam berbagai sengketa. Aturan hukum yang dirumuskan dalam bahasa, seringkali merupakan rumusan yang terbuka atau kabur tersebut. Singkatnya aturan hukum, dalam rumus yang membingungkan dan hanya dapat diterapkan apabila kebingungan itu sudah teratasi. ${ }^{59}$ Jika melihat pendapat Montesquieu, langkah rechtsvinding yang dibutuhkan pun tidak tercapai, dimana Hakim adalah corong undang-undang

\footnotetext{
59 Philipus M. Hadjon \& Tatiek Sri Djatmiati,
} op.cit, h.24 
(hakim menerapkan Undang-Undang dan melaksanakan secara harfiah) atau setiap hakim harus mengatakan sebagaimana yang termaktub dalam undang-undang atas segala kegiatan atau aktivitasnya agar tidak terjebak dalam situasi yang kacau atau hakim sebagai corong undang-undang, sebagai penerjemah undang-undang, dan sebagai orang-orang yang baik yang menilai dari sudut keadilan; ${ }^{60}$ padahal secara yuridis, UndangUndang Pornografi telah memberikan panduan mengenai ancaman pidana yang dapat dijatuhkan dalam perkara tersebut.

Jika putusan tersebut dibahas berdasar Teori Muller maka dapat diartikan akibat preventif (pencegahan) dari penjatuhan tindak pidana dalam putusan tidak tercapai, dikarenakan penentuan pidana oleh hakim tidak dilakukan secara konkret sesuai acuan yuridis yang tertera pada UndangUndang Pornografi sebagai UndangUndang yang ketentuan pidananya lebih berat dibandingkan UndangUndang Informasi dan Transaksi Elektronik dalam perkara tersebut.

Meninjau pendapat mengenai prevensi (pencegahan) sebagaimana disampaikan oleh Van Hamel dan Von Liszt, maka jika putusan pidana tidak memuat suatu unsur menakutkan maka pencegahan pelaku mengulangi melakukan perbuatannya atau mencegah bakal pelanggar melaksanakan perbuatan jahat yang direncanakannya tidak tercapai. Dalam konteks yang lebih jauh, pemenjaraan yang singkat dapat memunculkan segi negatifnya, yaitu penjahat pemula malah belajar di penjara kepada penjahat yang lebih

60 lbid. berpengalaman, sehingga tujuan pencegahan dan korektif justru tidak tercapai, bahkan sebaliknya.

\section{Kesimpulan}

1. Undang-Undang Pornografi memuat ketentuan yang menunjukkan semangat perlindungan hukum terhadap anak. Sejak di Pasal 1, sudah didefinisikan mengenai kategori anak. Dalam tujuan UndangUndang, sudah disebutkan bahwa salah satu tujuannya adalah melindungi anak. Dalam Larangan dan Pembatasan, juga berulang kali disebutkan mengenai perlindungan hukum kepada anak. Bahkan dalam ketentuan pidana, disebutkan bagi yang melibatkan anak termasuk tetapi tidak terbatas sebagai objek ditambah sepertiga dari maksimum ancaman pidananya. Namun Undang-Undang Pornografi tidak memberikan ancaman pemberatan sepertiga dari maksimum ancaman pidana jika tindakan pidana yang dilakukan adalah dalam bentuk melibatkan anak dalam menggunakan produk atau jasa pornografi.

2. Dalam putusan Nomor 1363/Pid.Sus/2017/PN JKT.SEL, Undang-Undang Pornografi disebutkan sebagai acuan dalam amar putusan selain UndangUndang Informasi dan Transaksi Elektronik, namun dalam penjatuhan pidana penjara dan pidana denda dalam putusan tidak menunjukkan bahwa yang digunakan adalah ketentuan pidana dalam Undang-Undang Pornografi. Padahal menurut Kitab Undang- 
Undang Hukum Pidana, jika ada aturan yang berbeda maka yang lebih berat ketentuan pidananya yang digunakan.

\section{E. Daftar Pustaka}

\section{Buku}

Akhdhiat, Hendra \& Rosleni Marliany. Psikologi Hukum. Bandung : CV Pustaka Setia, 2011.

Ali, Achmad. Sosiologi Hukum ; Kajian Empiris Terhadap Pengadilan. Jakarta : Penerbit STIH IBLAM, 2004.

Arief, Barda Nawawi. Beberapa Aspek Kebijakan Penegakan dan Pengembangan Hukum Pidana. Bandung : Citra Aditia Bakti, 1998.

Hadjon, Philipus M. \& Tatiek Sri Djatmiati. Argumentasi Hukum. Yogyakarta : Gadjah Mada University Press, 2017.

Hamzah, Andi. Asas-Asas Hukum Pidana. Jakarta : Rineka Cipta, 2010.

Krisnayuda, Backy. Pancasila dan Undang-Undang : Relasi dan Transformasi Keduanya dalam Sistem Ketatanegaraan Indonesia. Jakarta PrenadaMedia Group, 2016.

Moeljatno. Kitab Undang-Undang Hukum Pidana. Jakarta : Bumi Aksara, 2016.

Muchsin. Ikhtisar Sejarah Hukum. Jakarta : Penerbit STIH IBLAM, 2004.

Nasrullah, Rulli. Media Sosial Perspektif Komunikasi, Budaya dan Sosioteknologi. Bandung : Simbiosa Rekatama Media, 2015.
Nasrullah, Rulli. Komunikasi Antar Budaya di Era Budaya Siber. Jakarta : Prenada Media Group, 2012.

Rohman, Muhammad \& Sofan Amri. Manajemen Pendidikan Analisis dan Solusi terhadap Kinerja Manajemen Kelas dan Strategi Pengajaran yang Efektif. Jakarta : Prestasi Pustaka, 2012.

Rakhmat, Jalaluddin. Psikologi Komunikasi. Bandung : Remaja Rosdakarya, 2012.

Rumokoy, Donald Albert \& Frans Marantis. Pengantar Ilmu Hukum. Jakarta : Rajawali Pers, 2014.

Sembiring, Rosnidar. Hukum Keluarga : Harta-harta Benda dalam Perkawinan. Jakarta : Rajawali Pers, 2016.

Soekanto, Soerjono \& Mustafa Abdullah. Sosiologi Hukum dalam Masyarakat. Jakarta : CV Rajawali, 1980.

Soekanto, Soerjono. Pengantar Penelitian Hukum. Jakarta : UI Press, 2010.

Undang-Undang

Undang-Undang Dasar Negara Republik Indonesia Tahun 1945.

Undang-Undang Republik Indonesia Nomor 39 Tahun 1999 Tentang Hak Asasi Manusia.

Undang-Undang Republik Indonesia Nomor 35 Tahun 2014 Tentang Perubahan Atas UndangUndang Nomor 23 Tahun 2002 Tentang Perlindungan Anak.

Undang-Undang Republik Indonesia Nomor 19 Tahun 2016 tentang Perubahan Atas UndangUndang Nomor 11 Tahun 2008 Tentang Informasi Dan Transaksi Elektronik. 
Undang-Undang Republik Indonesia Nomor 44 Tahun 2008 Tentang Pornografi.

\section{Internet}

Badan Pengembangan dan Pembinaan Bahasa, Kementerian Pendidikan dan Kebudayaan Republik Indonesia, 2016. "Kamus Besar Bahasa Indonesia", https://kbbi.kemdikbud.go.id/ent ri/Objek (Diakses, 12 Agustus 2020)

Febriansyah. 2019. "Penelitian Ungkap Sexting Banyak Dilakukan Remaja”, https://tirto.id/penelitianungkap-sexting-banyakdilakukan-remaja-dgM2. Diakses pada 9 April 2020.

Icjr.or.id., "Pengungkapan Kasus Video Gay Kids (VGK): langkah maju Pemberantasan Child Online Pornography (COP) di Indonesia", 23 September 2017. <https://icjr.or.id/pengungkapa n-kasus-video-gay-kids-vgklangkah-maju-pemberantasanchild-online-pornography-copdi-indonesia/ (Diakses, 9 April 2020)

Id.wikipedia.org, "Anomie", 20 Maret 2020.

$<$ https://id.wikipedia.org/wiki/A nomie> (Diakses, 16 April 2020)

Kurniawan, Aris. 2019. "Teknologi Informasi dan Komunikasi Sejarah, Pengertian, Manfaat, Dampak, Pengelompokan, Komponen, Pendidikan, Klasifikasi" https://www.gurupendidikan.co. id/teknologi-informasi-dankomunikasi/. Diakses pada 2 April 2020.

Siadari, Ray Pratama. "Teori Perlindungan Hukum", https://raypratama.blogspot.com /2015/04/teori-perlindunganhukum.html. Diakses pada 16 April 2020 